\title{
Hybrid BFPSO algorithm based estimation of optimal drug dosage for antiretroviral therapy in HIV-1 infected patients
}

\author{
K Kamalanand, P Mannar Jawahar \\ From 2nd International Science Symposium on HIV and Infectious Diseases (HIV SCIENCE 2014) \\ Chennai, India. 30 January - 1 February 2014
}

\section{Background}

Although the use of anti retroviral drugs has prolonged the life of infected patients, the side effects can be severe. The objective of this work is to efficiently estimate the optimal drug dosage for ART using mathematical model based method.

\section{Methods}

In this work, an artificial intelligence technique known as the hybrid Bacterial Foraging Particle Swarm Optimization (BFPSO) algorithm is used in conjunction with the three dimensional patient specific HIV model, for estimation of optimal drug concentration. In the mathematical model, it is assumed that the drug acts directly on the viral burden. The optimization problem is formulated in such a way that the HIV-1 viral load as well as the total drug concentration is minimized.

\section{Results}

Based on the computer simulation studies performed for a particular case at the seventh year of infection, it was found that in the scenario without therapy, the CD4 cell count dropped to a value of 366 cells $/ \mathrm{mm}^{3}$. However, when ART is administered based on the hybrid BFPSO algorithm, the CD4 cell count increased to a value of 782 cells $/ \mathrm{mm}^{3}$, with minimal usage of the drug concentration.

\section{Conclusion}

Results demonstrate that, the optimal drug dosage estimated using the proposed methodology is efficient in improving the immune system and minimizing the viral burden. This work seems to be of high clinical importance

* Correspondence: pmjmit@gmail.com

Madras Institute of Technology Campus, Anna University, Chennai, India since, at present; ART is the widely used method for treatment of HIV-1 infection.

Published: 27 May 2014

doi:10.1186/1471-2334-14-S3-E14

Cite this article as: Kamalanand and Jawahar: Hybrid BFPSO algorithm based estimation of optimal drug dosage for antiretroviral therapy in HIV-1 infected patients. BMC Infectious Diseases 2014 14(Suppl 3):E14.
Submit your next manuscript to BioMed Central and take full advantage of:

- Convenient online submission

- Thorough peer review

- No space constraints or color figure charges

- Immediate publication on acceptance

- Inclusion in PubMed, CAS, Scopus and Google Scholar

- Research which is freely available for redistribution

Submit your manuscript at www.biomedcentral.com/submit
() Biomed Central 